\title{
Karyotypes of two rare rodents, Hapalomys delacouri and Typhlomys cinereus (Mammalia, Rodentia), from Vietnam
}

\author{
Alexei V. Abramov ${ }^{1,3}$, Vladimir M. Aniskin², Viatcheslav V. Rozhnov ${ }^{2,3}$ \\ I Zoological Institute, Russian Academy of Sciences, Universitetskaya nab. 1, Saint-Petersburg 199034, Russia \\ 2 A.N. Severtsov Institute of Ecology and Evolution, Russian Academy of Sciences, Leninskii pr., 33, Moscow \\ 119071, Russia 3 Joint Vietnam-Russian Tropical Research and Technological Centre, Nguyen Van Huyen, \\ Nghia Do, Cau Giay, Hanoi, Vietnam
}

Corresponding author:Alexei V.Abramov (a.abramov@mail.ru)

Academic editor: K. M. Helgen | Received 8 July 2011 | Accepted 21 December 2011 | Published 11 January 2012

Citation: Abramov AV, Aniskin VM, Rozhnov VV (2012) Karyotypes of two rare rodents, Hapalomys delacouri and Typhlomys cinereus (Mammalia, Rodentia), from Vietnam. ZooKeys 164: 41-49. doi: 10.3897/zookeys.164.1785

\begin{abstract}
Karyotypes of Hapalomys delacouri (Rodentia, Muridae) and Typhlomys cinereus (Rodentia, Platacanthomyidae) from Vietnam are described for the first time. The diploid karyotype of $H$. delacouri is 38 $(\mathrm{NFa}=48)$, consisting of six pairs of bi-armed and 12 pairs of acrocentric autosomes decreasing in size; plus a large metacentric $\mathrm{X}$ chromosome and $\mathrm{Y}$ chromosome, also metacentric, that is equal in size to the largest pair of acrocentric autosomes. The newly described karyotype differs significantly from that reported for $H$. delacouri from northern Thailand. The latter record very likely represents a different species of Hapalomys, possibly the taxon $H$. pasquieri described from north-central Laos. The diploid karyotype of Typhlomys cinereus is $38(\mathrm{NF}=48)$, consisting of five pairs of meta- to submetacentric and 14 pairs of acrocentric chromosomes varying in size from large to small; sex chromosomes were not defined.
\end{abstract}

\section{Keywords}

karyotypes, Hapalomys delacouri, Hapalomys pasquieri, Typhlomys cinereus, Vietnam

\section{Introduction}

According to the recent checklist by Can et al. (2008), the mammal fauna of Vietnam consists of 295 species. During recent years, a half of dozen of new species have been found in Vietnam, including shrews, bats and a rodent (Jenkins et al.

Copyright Alexei V. Abramov et al. This is an open access article distributed under the terms of the Creative Commons Attribution License 3.0 (CC-BY), which permits unrestricted use, distribution, and reproduction in any medium, provided the original author and source are credited. 
2009, 2010, Borisenko et al. 2009, Tran et al. 2009, Bannikova et al. 2011). Rodents represent one of the most diverse but yet taxonomically neglected group of Vietnamese mammals.

It is well known that karyological data can be useful for tackling problems of rodent taxonomy and evolution (Volobouev et al. 2002, 2007, Aniskin et al. 2006, Kovalskaya et al. 2011). Therefore, cytotaxonomy represents an important step toward the inventory of the rodent species of Vietnam (Duncan et al. 1970, Cao and Tran 1985, Baskevich and Kuznetsov 1998). In the present paper, the karyotypes of two rare and poorly-known Vietnamese rodents - Hapalomys delacouri and Typhlomys cinereus - are described for the first time.

\section{Material and methods}

A number of rare and poorly-known mammal species were collected during a biodiversity surveys carried out by the Joint Vietnam-Russian Tropical Research and Technological Centre in 2010. Voucher specimens are deposited in the Zoological Institute of the Russian Academy of Sciences (ZIN), Saint-Petersburg, Russia. Five specimens of the marmoset rat Hapalomys delacouri Thomas, 1927 were collected in southern Vietnam, NE of Bu Gia Map Village, Binh Phuoc Province $\left(12^{\circ} 12^{\prime} \mathrm{N}, 107^{\circ} 12^{\prime} \mathrm{E}\right.$; ZIN 98922, 99486-99488, 100410). A specimen of the soft-furred tree mouse Typhlomys cinereus Milne-Edwards, 1877 was collected in northern Vietnam, near Tram Ton Station of Hoang Lien National Park, W of Sa Pa Village, Lao Cai Province $\left(22^{\circ} 21^{\prime} \mathrm{N}\right.$, $103^{\circ} 46^{\prime} \mathrm{E}$; ZIN 100411). The collecting localities are shown in Fig.1.

The rodents were caught alive using locally made cage traps. The specimens were immediately brought to the laboratory where they were karyotyped. Chromosome analysis was carried out on preparations obtained from bone marrow following the standard colchicines method (Ford and Hamerton 1956). Slides were stained with $4 \%$ Giemsa in phosphate buffer with $\mathrm{pH}=6.8$. At least 20 quality metaphases were analyzed for each specimen.

\section{Results and discussion}

\section{Hapalomys delacouri Thomas, 1927 - lesser marmoset rat}

The marmoset rats have very distinct external and cranial characteristics which preclude an incorrect generic identification (Thomas 1927, Musser 1972, Corbet and Hill 1992) - see Fig. 2.

The diploid chromosome number is $2 \mathrm{n}=38, \mathrm{NFa}=48$ (Fig. 3A). This karyotype consists of six pairs of bi-armed and 12 pairs of acrocentric autosomes decreasing in size, with a large metacentric $\mathrm{X}$ chromosome and with $\mathrm{Y}$ chromosome, also metacentric, which is equal in size to the largest pair of acrocentric autosomes. 


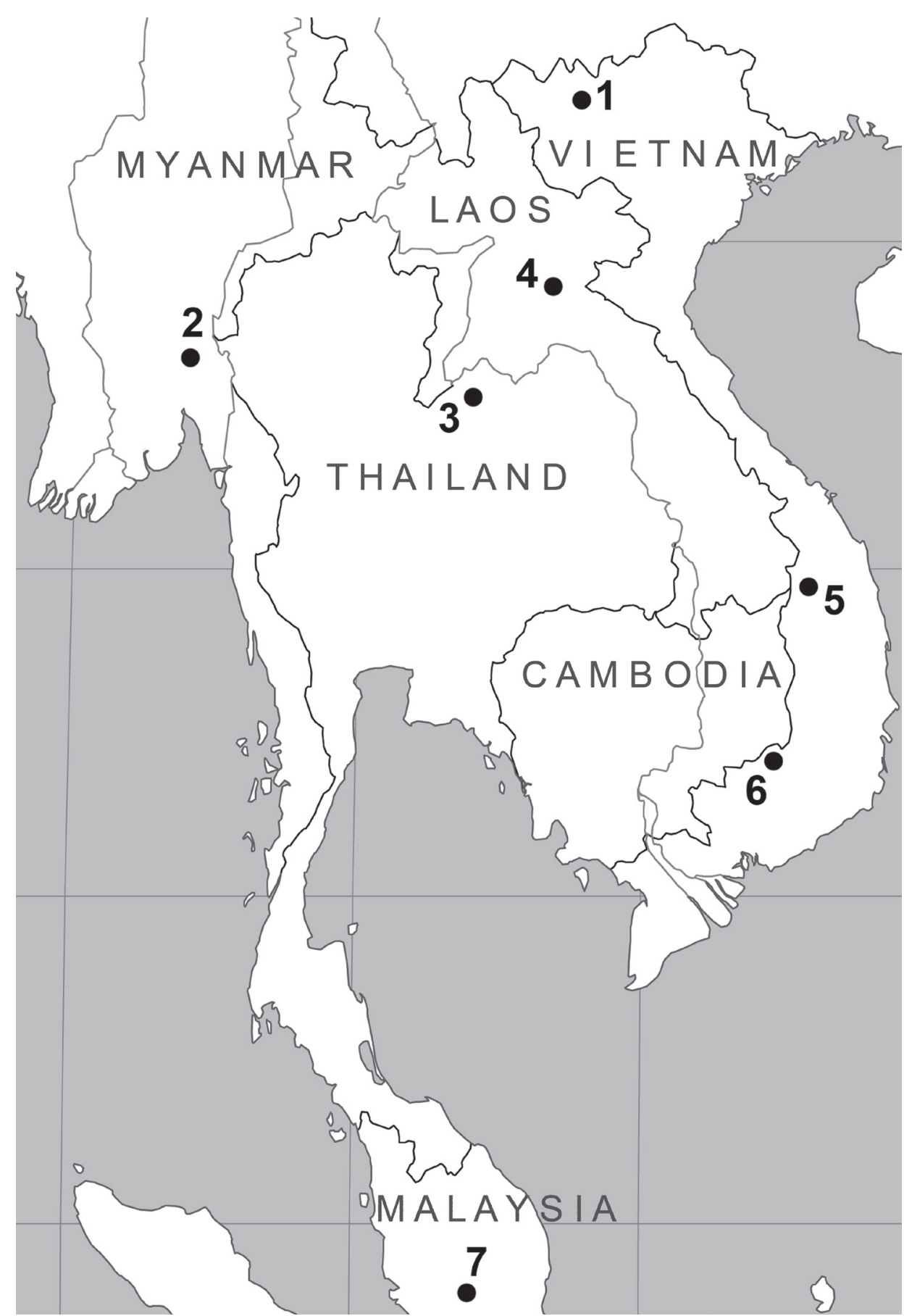

Figure I. Map of localities. I sampling locality of Typhlomys cinereus $\mathbf{2}$ type locality of Hapalomys longicaudatus $\mathbf{3}$ locality from Badenhorst et al. $2009 \mathbf{4}$ type locality of Hapalomys pasquieri $\mathbf{5}$ type locality of Hapalomys delacouri $\mathbf{6}$ sampling locality of Hapalomys delacouri in Bu Gia Map $\mathbf{7}$ approximate locality for Hapalomys longicaudatus record from Yong et al. 1982. 


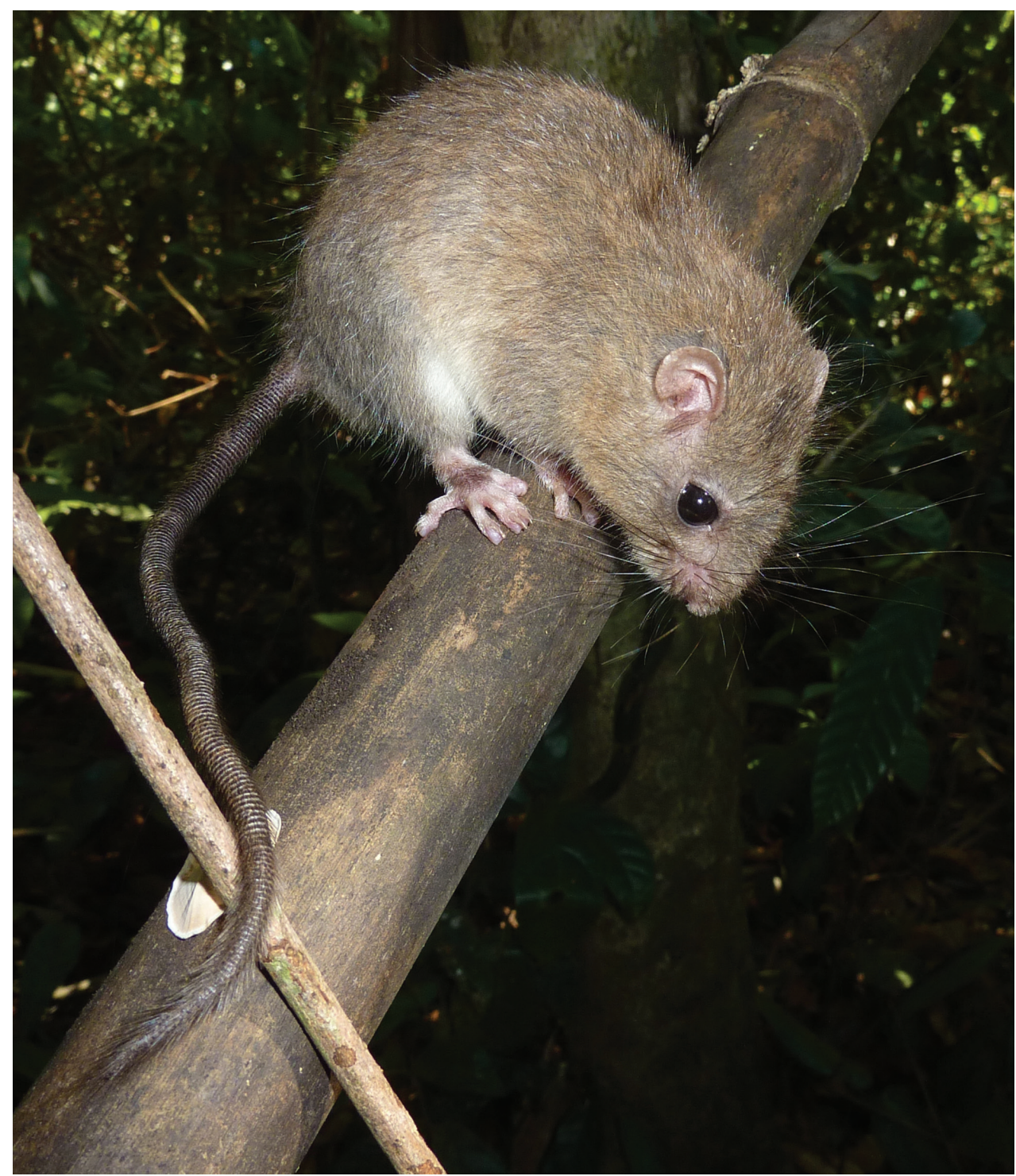

Figure 2. Hapalomys delacouri. Adult male from Bu Gia Map, Binh Phuoc Province, southern Vietnam. Photographed by Alexei V. Abramov.

The observed karyotype differs significantly from that described by Badenhorst et al. (2009) for $H$. delacouri from Loei, northern Thailand (see Fig. 1). The latter authors reported the karyotype as having $2 \mathrm{n}=48$ and $\mathrm{NFa}=92$. All the autosomes were biarmed (metacentric or submetacentric). The metacentric $\mathrm{X}$ and the acrocentric $\mathrm{Y}$ were easily recognizable because they were, respectively, the largest and the smallest elements in the karyotype. Earlier, Yong et al. (1982) described the karyotype of Hapalomys longicaudatus Blyth, 1859 based on a specimen from Malaysia. The diploid number of this 


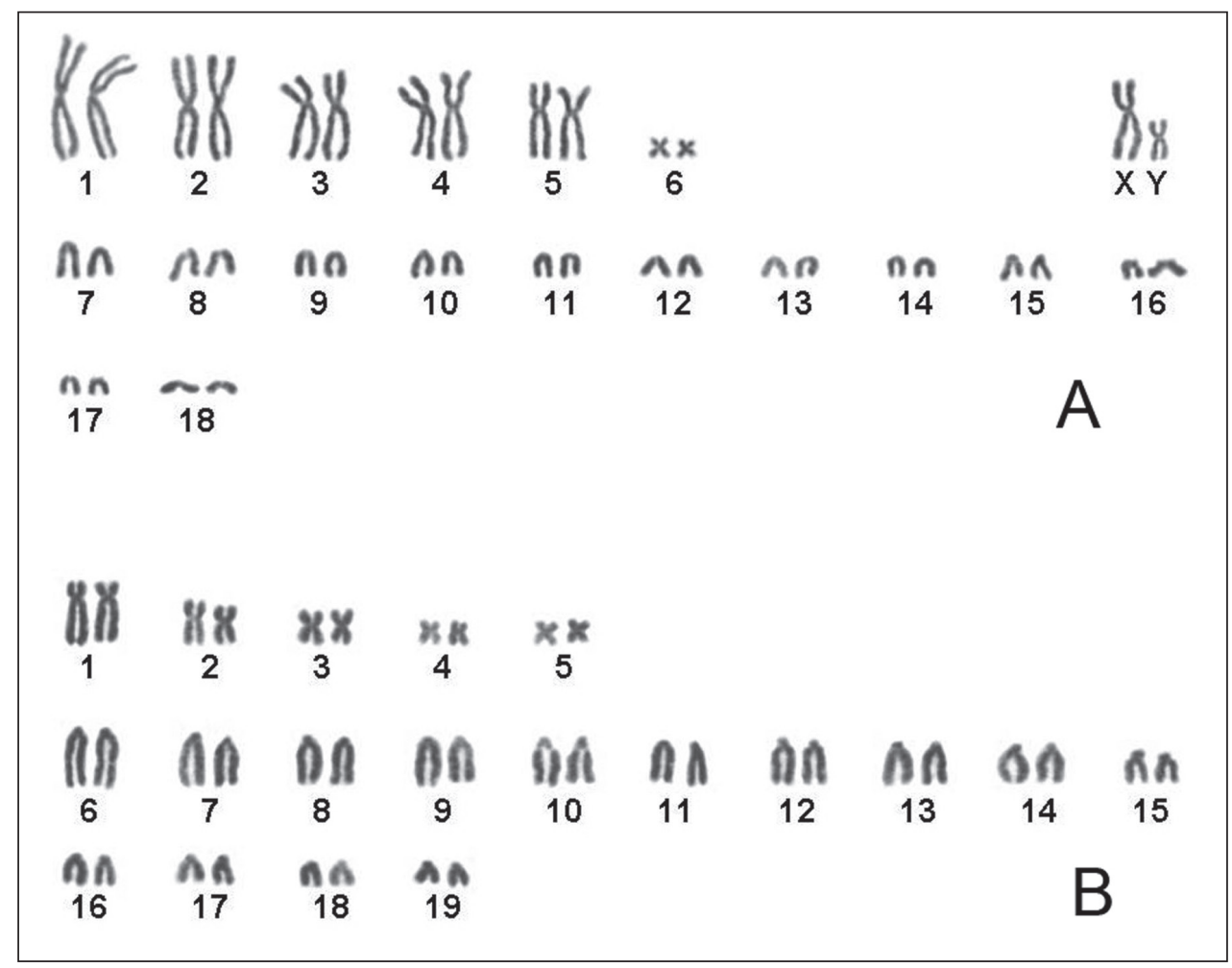

Figure 3. A Karyotype of male Hapalomys delacouri (ZIN 100410), $2 \mathrm{n}=38, \mathrm{NFa}=48$ B Karyotype of female Typhlomys cinereus (ZIN 100411), 2n=38, NF=48.

specimen was $2 \mathrm{n}=50$, consisting of 23 pairs of uniarmed and 1 pair of small bi-armed autosomes, metacentric $\mathrm{X}$ and subacrocentric $\mathrm{Y}$ sex chromosomes. The $\mathrm{X}$ chromosome was the largest element in the complement and constituted about $7.8 \%$ of the female haploid complement. The Y-chromosome was also distinct, being the only morphological type among the larger sized chromosomes, and constituted about $5.2 \%$ of the female haploid complement.

According to recent taxonomic studies (Musser and Carleton 1993, 2005, Nowak 1999), the genus Hapalomys consists of two species - delacouri and longicaudatus - distributed in eastern and western parts of Southeast Asia, respectively. The two species differ in coloration and size (Thomas 1927, Musser 1972, Corbet and Hill 1992). The specimens from Bu Gia Map are similar in coloration, size and body proportions (Table 1) to the lesser marmoset rat $H$. delacouri, which was described by Thomas (1927) from Kon Tum Province in southern Vietnam (Fig. 1). Another form of the marmoset rats was described by Thomas (1927) as Hapalomys pasquieri from Xieng Khouang in northern Laos (Fig. 1). Musser (1972) considered this form as a subspecies of $H$. delacouri based on similarities in coloration. Strong karyological differences between our specimen taken from southern Vietnam and the specimen from northern 
Table I. External and cranial measurements (range and means, in mm) of Hapalomys spp. The cranial measurements are explained in Musser (1970).

\begin{tabular}{l|l|l|l|l}
\hline Measurements & $\begin{array}{l}\text { longicaudatus } \\
\text { (from Musser } \\
\mathbf{1 9 7 2}), \mathbf{n}=\mathbf{3 - 4}\end{array}$ & $\begin{array}{l}\text { delacouri } \\
\text { (from Musser } \\
\mathbf{1 9 7 2}), \mathbf{n}=\mathbf{4 - 5}\end{array}$ & $\begin{array}{l}\text { delacouri } \\
\text { Bu Gia Map, } \\
\mathbf{n = 4}\end{array}$ & $\begin{array}{l}\text { pasquieri } \\
\text { (from Musser } \\
\mathbf{1 9 7 2}), \mathbf{n}=\mathbf{1}\end{array}$ \\
\hline $\begin{array}{l}\text { Length of head and } \\
\text { body }\end{array}$ & $162-165(163.5)$ & $123-136(131.0)$ & $130-146(136.7)$ & 121.0 \\
\hline Length of tail & $193-202(198.3)$ & $140-160(149.2)$ & $155-165(160.0)$ & 171.0 \\
\hline $\begin{array}{l}\text { Greatest length of } \\
\text { skull }\end{array}$ & $39.7-41.5(40.47)$ & $33.6-34.2(34.00)$ & $\begin{array}{l}34.6-35.7 \\
(35.10)\end{array}$ & 32.0 \\
\hline Length of nasals & $11.5-12.6(12.25)$ & $11.7-12.0(11.87)$ & $\begin{array}{l}11.7-11.9 \\
(11.72)\end{array}$ & 10.5 \\
\hline Length of rostrum & $9.7-10.2(9.93)$ & $9.3-9.7(9.47)$ & $9.4-10.0(9.66)$ & 8.3 \\
\hline Height of brain case & $11.2-12.0(11.63)$ & $9.1-9.5(9.33)$ & $9.1-9.7(9.49)$ & 9.0 \\
\hline Palatal length & $18.1-22.3(20.78)$ & $16.9-18.0(17.48)$ & $\begin{array}{l}17.4-18.2 \\
(17.83)\end{array}$ & 15.8 \\
\hline Maxillary tooth-row* & $7.9-8.0$ & ca. 6.3 & $6.3-6.6(6.4)$ & ca. 5.9 \\
\hline
\end{tabular}

* Data from Corbet and Hill (1992) except for our specimens.

Thailand recorded by Badenhorst et al. (2009) point to a species level divergence. On distributional grounds (Fig. 1) the species in northern Thailand is most likely $H$. pasquieri but this needs confirmation by morphological comparison of the Thai and Laotian specimens. Further taxonomic studies of the genus Hapalomys are needed and cytotaxonomy can be a valuable tool for diagnosing the species involved.

\section{Typhlomys cinereus Milne-Edwards, 1877 - soft-furred tree mouse}

The diploid chromosome number is $2 \mathrm{n}=38, \mathrm{NF}=48$ (Fig. 3B), consisting of five pairs of meta- to submetacentric and 14 pairs of acrocentric chromosomes varying in size from large to small. Sex chromosomes of $T$. cinereus have not defined, as the female only was karyotyped in this study. It is the first karyotype described for a representative of the genus Typhlomys.

The soft-furred tree mouse, or pygmy dormouse, Typhlomys cinereus (Fig. 4) belongs to the enigmatic family Platacanthomyidae, the earliest phylogenetic offshoot within Muroidea (Jansa et al. 2009). It is best known from mountain forests of southern China, with an outlying population at high elevations in the northern part of Hoang Lien Mts in northern Vietnam (Nowak 1999, Musser and Carleton 2005, Can et al. 2008). The Vietnamese population was described as a separate species, Typhlomys chapensis (Osgood 1932) but it is now considered a subspecies of T. cinereus (Musser and Carleton 2005). Further morphological and genetic studies are needed to clarify the taxonomic status of the Vietnamese soft-furred tree mouse. 


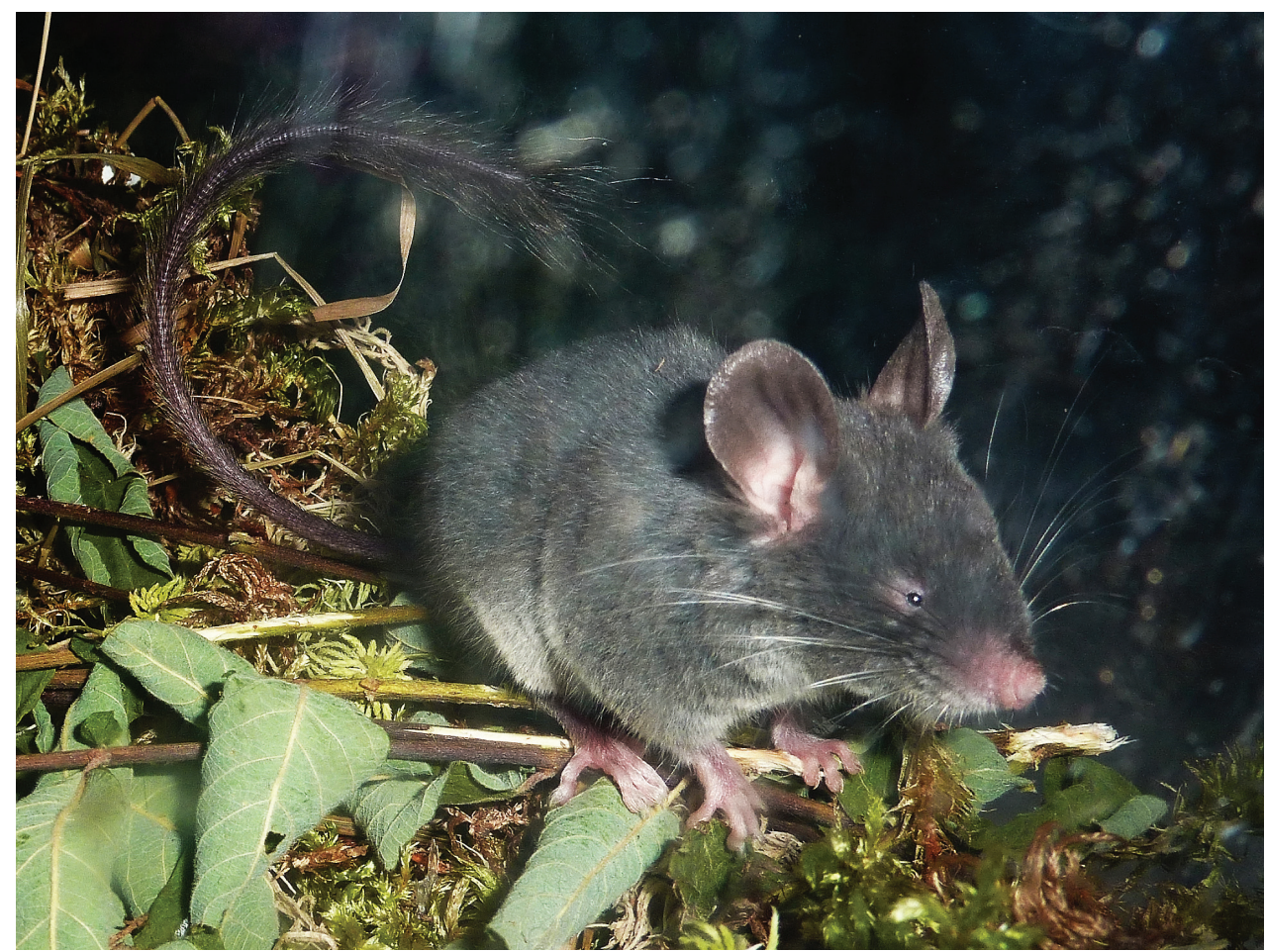

Figure 4. Typhlomys cinereus. Adult female from Sa Pa, Lao Cai Province, northern Vietnam. Photographed by Alexei V. Abramov.

\section{Acknowledgements}

We are grateful to the administration of the Bu Gia Map Nature Reserve and Hoang Lien National Park for providing us with an opportunity to carry out field surveys. We would like to express our sincere thanks to A.V. Shchinov, S.V. Kruskop and all expedition members of the Joint Vietnam-Russian Tropical Research and Technological Centre for their great help and scientific expertise during the field works. We are obliged to Dmitri Logunov (Manchester, UK) for assistance with English language. We are grateful to Ken Aplin and anonymous reviewer for useful comments on an earlier draft. This work was supported in part by the Ministry of Education and Science of Russian Federation.

\section{References}

Aniskin VM, Benazzou T, Biltueva L, Dobigny G, Granjon L, Volobouev V (2006) Unusually extensive karyotype reorganization in four congeneric Gerbillus species (Muridae: Gerbillinae). Cytogenetic and Genome Research 112: 131-140. doi: 10.1159/000087525 
Badenhorst D, Herbreteau V, Chaval Y, Pages M, Robinson TJ, Rerkamnuaychoke W, Morand S, Hugot J-P, Dobigny G (2009) New karyotypic data for Asian rodents (Rodentia, Muridae) with the first report of B-chromosomes in the genus Mus. Journal of Zoology 279: 44-56. doi: 10.1111/j.1469-7998.2009.00588.x

Bannikova AA, Abramov AV, Borisenko AV, Lebedev VS, Rozhnov VV (2011) Mitochondrial diversity of the white-toothed shrews (Mammalia, Eulipotyphla, Crocidura) in Vietnam. Zootaxa 2812: 1-20.

Baskevich MI, Kuznetsov GV (1998) Cytogenetic differentiation of species from the genus Rattus (Rodentia, Muridae) from the Dalat Plateau in southern Vietnam. Zoologicheskii Zhurnal 77: 1321-1328.

Borisenko AV, Kruskop SV, Ivanova NV (2009) A new mouse-eared bat (Mammalia: Chiroptera: Vespertilionidae) from Vietnam. Russian Journal of Theriology 7: 57-69.

Can DN, Endo H, Son NT, Oshida T, Canh LX, Phuong DH, Lunde DP, Kawada S-I, Hayashida A, Sasaki M (2008) Checklist of Wild Mammal Species of Vietnam. Institute of Ecology and Biological Resources, Hanoi, 400 pp.

Cao VS, Tran VM (1985) Karyotypes et systematique des rats (genre Rattus Fischer) du Vietnam. Mammalia 48: 557-564.

Corbet GB, Hill JE (1992) The Mammals of the Indomalayan Region: A Systematic Review. Oxford University Press, Oxford, 488 pp.

Duncan JF, van Peenen PFD, Ryan PF (1970). Somatic chromosomes of eight mammals from Con Son Island, South Vietnam. Caryologia 23: 173-181.

Ford CE, Hamerton JL (1956) A colchicines, hypotonic citrate, squash sequence for mammalian chromosomes. Stain Technology 31: 247-251.

Jansa SA, Giarla TC, Lim BK (2009) The phylogenetic position of the rodent genus Typhlomys and the geographic origin of Muroidea. Journal of Mammalogy 90: 1083-1094. doi: 10.1644/08-MAMM-A-318.1

Jenkins PD, Lunde DP, Moncrieff CB (2009) Chapter 10. Descriptions of new species of Crocidura (Soricomorpha: Soricidae) from mainland Southeast Asia, with synopses of previously described species and remarks on biogeography. In: Voss RS, Carleton MC (Eds) Systematic Mammalogy: Contributions in Honour of Guy G. Musser. Bulletin of the American Museum of Natural History 331: 356-405.

Jenkins PD, Abramov AV, Rozhnov VV, Olsson A (2010) A new species of Crocidura (Soricomorpha: Soricidae) from southern Vietnam and north-eastern Cambodia. Zootaxa 2345: 60-68.

Kovalskaya YM, Aniskin VM, Bogomolov PL, Surov AV, Tikhonov IA, Tikhonova GN, Robinson TJ, Volobouev VT (2011) Karyotype reorganisation in the subtilis group of birch mice (Rodentia, Dipodidae, Sicista): unexpected taxonomic diversity within a limited distribution. Cytogenetic and Genome Research 132: 271-288. doi: 10.1159/000322823

Musser GG (1970) Species-limits of Rattus brahma, a murid rodent of northeastern India and northern Burma. American Museum Novitates: 2406: 1-27.

Musser GG (1972) The species of Hapalomys (Rodentia, Muridae). American Museum Novitates 2503: 1-27. 
Musser GG, Carleton MD (1993) Family Muridae. In: Wilson DE, Reeder DM (Eds) Mammal Species of the World. A Taxonomic and Geographic Reference. Second edition. Smithsonian Institute Press, Washington, 501-755.

Musser GG, Carleton MD (2005) Superfamily Muroidea. In: Wilson DE, Reeder DM (Eds) Mammal Species of the World. A Taxonomic and Geographic Reference. Third edition. Johns Hopkins University Press, Baltimore, 2, 894-1531.

Osgood WH (1932) Mammals of the Kelley-Roosevelts and Delacour Asiatic expeditions. Field Museum of Natural History, Zoological Series 18: 193-339.

Nowak RM (1999) Walker's Mammals of the World. Sixth edition. John Hopkins University Press, Baltimore and London, 2, 837-1936.

Thomas O (1927) The Delacour Expedition of French Indochina - mammals. Proceedings of Zoological Society of London 1927(1): 41-58.

Tran HH, Viet TH, Canh LX, Dang NX (2009) New genus and species of stripe-bellied rat Pseudoberylmys muongbangensis Tran H.H., T.H. Viet, L. X. Canh, N. X. Dang, 2008 gen. sp.nov. (Mammalia, Rodentia, Muridae) from Vietnam. Journal of Biology, Hanoi 31(2): 33-39.

Volobouev VT, Ducroz J-F, Aniskin VM, Britton-Davidian J, Castiglia R, Dobigny G, Granjon L, Lombard M, Corti M, Sicard B, Capanna E (2002) Chromosomal characterization of Arvicanthis species (Rodentia, Murinae) from western and central Africa: implications for taxonomy. Cytogenetic and Genome Research 96: 250-260. doi: 10.1159/000063041

Volobouev V, Aniskin VM, Sicard B, Dobigny G, Granjon L (2007) Systematics and phylogeny of West African gerbils of the genus Gerbilliscus (Muridae: Gerbillinae) inferred from comparative G- and C-banding chromosomal analyses. Cytogenetic and Genome Research 116: 269-281. doi: 10.1159/000100411

Yong HS, Dhaliwal SS, Lim L (1982) Karyotypes of Hapalomys and Pithecheir (Rodentia, Muridae) from Peninsular Malaysia. Cytologia 47: 535-538. doi: 10.1508/cytologia.47.535 
